\title{
BEHAVIOR OF BROILERS UNDER THE INFLUENCE OF LED LIGHTING AND MICROMETEOROLOGICAL ELEMENTS
}

\author{
Tatiana P. N. da S. Rodrigues ${ }^{1 *}$, Héliton Pandorfi ${ }^{2}$, Cristiane Guiselini ${ }^{2}$, Gledson L. P. de Almeida ${ }^{2}$, \\ Waldirene B. B. Morrill ${ }^{2}$
}

${ }^{1 *}$ Corresponding author. Maurício de Nassau University Center/ Recife - PE, Brazil.

E-mail: tatianapnsilva@hotmail.com | ORCID: https://orcid.org/0000-0003-4435-1112

KEYWORDS
animal welfare,
broiler farming,
lighting system,
principal component
analysis, thermal
comfort.

\begin{abstract}
The objective of this research was to analyze the differences between the food behaviors observed under the factors of production environment, sex and lighting system, using stochastic tools of multivariate analysis. As for the thermal characteristics of the environment, air temperature $\left(\mathrm{T},{ }^{\circ} \mathrm{C}\right)$, enthalpy $\left(\mathrm{H}, \mathrm{kJ} \mathrm{kg}^{-1}\right)$, and black globe temperature and humidity index (BGTHI) showed high positive correlation with each other and strong negative correlation with relative humidity $(\mathrm{RH}, \%)$. The "male drinking" behavior was positively associated with thermal characteristics of the environment in the three periods of the day, that is, the act of drinking more water would be a way to alleviate thermal stress. Birds subjected to red LED showed a strong negative correlation with temperature associated with the "female drinking" behavior, in the afternoon period, according to the principal component analysis, which is justified by the orientation of the broiler house with its longitudinal axis in the NE/SW direction, so the sunlight directly hits the area where the drinker was located. Variation in body weight showed better response when the birds were exposed to a temperature of $27^{\circ} \mathrm{C}$, for the $5^{\text {th }}$ week of the rearing cycle.
\end{abstract}

\section{INTRODUCTION}

Poultry farming in Brazil is the most prominent agricultural activity in the international market and has been the leader in exports and second place in world production since 2004, only behind the United States (Silva et al., 2015).

According to Costa et al. (2015), Brazil has achieved this place mainly due to the excellent structure of the supply chain and climate, which favor the production of birds and grains throughout its territory. The result of this investment is a product with quality, health and sustainability, which, combined with competitive prices, have led Brazilian chicken meat to more than 150 countries, not only because it is the most affordable animal protein source in the market, but also because it is a healthy, extremely nutritious and protein-rich food.

The intensification in its production process is also due to improvements in genetics, feeding, introduction of new technologies and management practice, as well as the use of more appropriate facilities, which favor animal welfare.
The increasingly controlled facilities offer equipment to meet physiological needs and explore the zootechnical potential of broilers (Abreu \& Abreu, 2011). Among the controlled equipment, the lighting system is fundamental in terms of both type of lighting and its distribution along the broiler house.

Artificial lighting is a tool used in poultry production and aims to improve food and water intake and consequently growth, resulting in the economic viability of the lot. The use of lighting system with light-emitting diode (LED) has stood out in poultry farming as it promotes savings in electricity and can be adjusted along the rearing process (Santana et al., 2014).

Light quality, levels and duration are extremely important for broilers. Light is one of the main factors of the microclimate that influences behavior, growth, physiological functioning, among others (Olanrewaju et al., 2016).

Studying animal behavior also assumes an important role in production because management techniques and

\footnotetext{
${ }^{2}$ Federal Rural University of Pernambuco/ Recife - PE, Brazil. 
facilities that interfere with and depend on animal behavior have been developed in order to rationalize the rearing methods. It is a challenge to keep the thermal environment balanced and, as birds alter their behavior in response to this environment, understanding their behavior helps in this control, because the production animals have their specific behavioral needs and are able to modify their behavior to adapt to the environment in which they live (Bergmann et al., 2017; Schiassi et al., 2015).

Based on the importance of the thermal environment and its influence on the behavior and yield of broilers, the objective of this study was to analyze the differences between the ingestive behaviors observed under the factors of the production environment, sex and lighting system, using stochastic tools of multivariate analysis.

\section{MATERIAL AND METHODS}

The database used in the study came from an experiment conducted at the Experimental Station of Small Animals (EEPAC/UFRPE), located in the municipality of Carpina, state of Pernambuco, Brazil (Figure 1), at $7.85^{\circ} \mathrm{S}$ latitude, $35.24^{\circ} \mathrm{W}$ longitude and altitude of $180 \mathrm{~m}$. The climate of the region is characterized as megathermal (As') with winter precipitation and dry season from summer to autumn, according to Köppen's classification (Pereira et al., 2002).

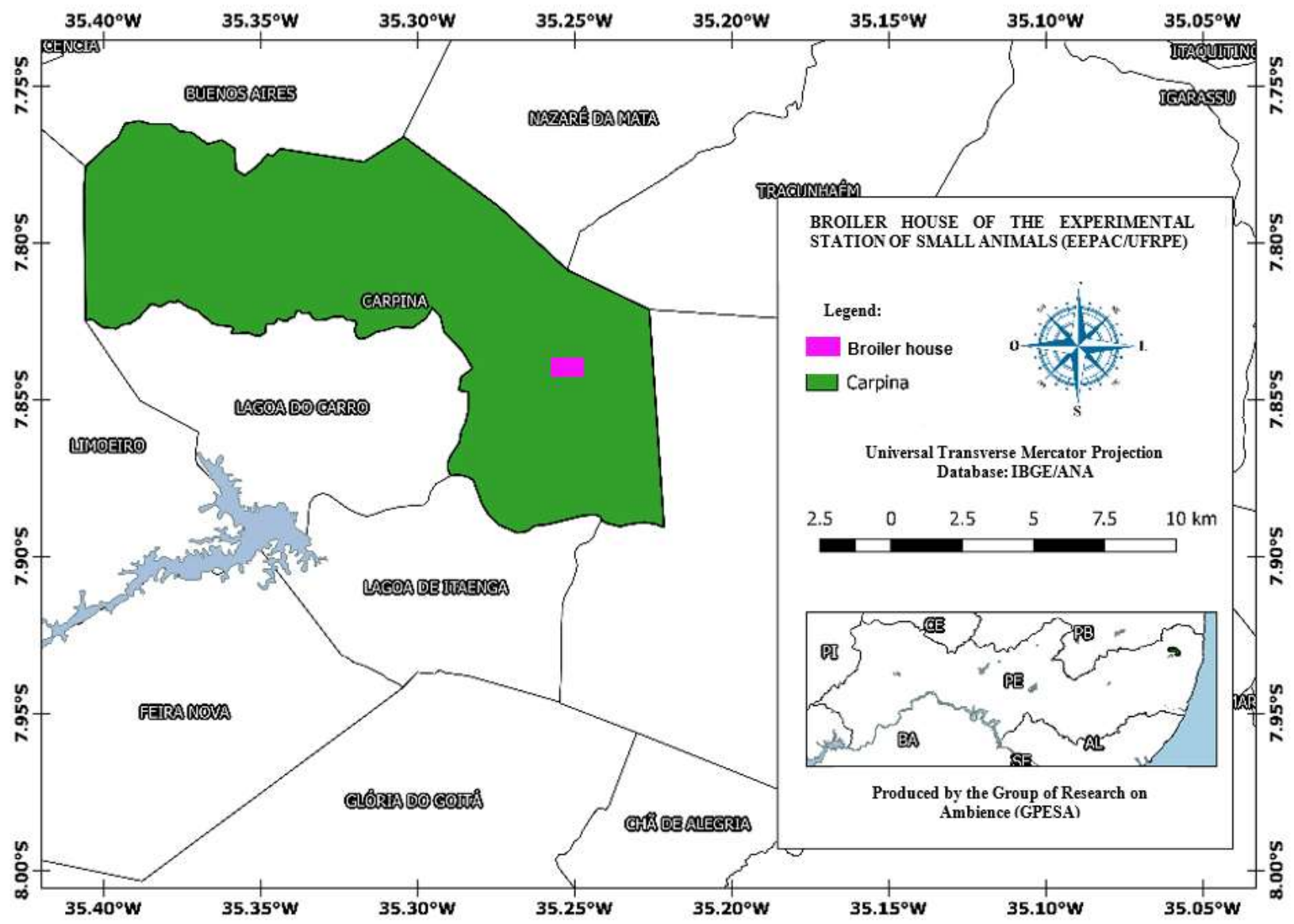

FIGURE 1. Study area location.

The experimental shed was $9.5 \mathrm{~m}$ wide and $33.0 \mathrm{~m}$ long, with ceiling height of $2.8 \mathrm{~m}$, without lining, 0.4-m high masonry wall and closure with polyethylene screen (22 $\mathrm{mm}$ ) in all the perimeter of the facility, associated with a blue-colored polypropylene curtains, which were managed according to the thermal need of the birds during the production cycle. The elementary shape of the roof had two pitches, covered with 6-mm-thick fiber cement roofing sheets, 1.5-m-long eaves, with ridge vent and NE/SW orientation. For this study, groups of 68 cobb 500 birds were distributed in 2 production pens, with 20 -cm-high masonry walls and polyethylene screen $(22 \mathrm{~mm})$, concrete floor and wood shaving bedding.

The birds were distributed in the pens according to the variation factors tested, lighting system and sex, with two repetitions for each lighting system, separated by polyethylene screen: T1 - males x red LED (660 nm); T2 - females $x$ red LED (660 nm); T3 - males x white LED (400$760 \mathrm{~nm}$ ) and T4 - females $x$ white LED (400-760 nm).

\section{Acquisition, recording and visual analysis of images}

Video images were subjected to visual analysis, considering the ingestive behaviors of birds, access to feeders, access to drinkers and inactivity. These behaviors were visually analyzed using the methodology of Schiassi et al. (2015), in which the behaviors were counted over an interval of 10 minutes every hour of the day, in the period of 24 hours, totaling 3456 frames/day, for the treatments.

\section{Evaluation of thermal environment and bird performance}

Hourly recording of the micrometeorological variables air temperature $\left(\mathrm{Ta},{ }^{\circ} \mathrm{C}\right)$, relative humidity $(\mathrm{RH}$, $\%$ ) and black globe temperature $\left(\mathrm{Tbg},{ }^{\circ} \mathrm{C}\right)$ was performed 
using HOBO U12-12 thermo-hygrometers (Onset Computer Corporation Bourne, MA, USA), which are mini data loggers whose purpose was to characterize the thermal efficiency within the housing.

Comparison between the different treatments was performed based on the black globe temperature and humidity index (BGTHI) proposed by Buffington et al. (1981) and the specific enthalpy index (H; kJ kg dry air $\left.{ }^{-1}\right)$ proposed by Rodrigues et al. (2011), according to eqs (1) and (2).

$$
\text { BGTHI }=\text { Tbg }+0.36 \times \text { Tdp }-330.08
$$

Where:

Tbg: black globe temperature $(\mathrm{K})$,

Tdp: dew point temperature (K).

$H=1.006 \cdot D B T+\frac{R H}{P_{a t m}} \cdot 10^{\left(\frac{7.5 \cdot D B T}{237.3+D B T}\right)} \cdot(71.28+0.052 \cdot D B T)$

Where:

DBT: dry bulb temperature $\left({ }^{\circ} \mathrm{C}\right)$;

RH: relative humidity (\%),

$\mathrm{P}_{\mathrm{atm}}$ : local atmospheric pressure $(\mathrm{mmHg})$.

The results of the image analysis were discussed based on gains in body weight, which was determined weekly by the difference between the final weight and the initial weight of the broilers, in each treatment, through weekly weighing, along the 42-day production cycle.

Principal component analysis (PCA) techniques were used to associate environmental variables and the ingestive behavior of broilers, observing the angle and magnitude of the vectors, in order to verify the influence of the environment on the behavior and productive performance of the birds.

The PCA was used to increase the visibility of a data set, reducing the number of variables. Thus, it was possible to verify whether the behavior of the broilers was influenced by the production environment and different types of LED lighting, and to observe whether there was an association of the mean frequency of occurrence of the behaviors with environmental variables and, this with the different types of lighting and sex of the birds. This statistical analysis was performed using R software.

\section{RESULTS AND DISCUSSION}

Figure 2 presents the thermal characterization of the pens subjected to white and red LED lights, in which it is verified that the BGTHI, enthalpy and air temperature are directly proportional to each other and inversely proportional to relative humidity. However, the period from $09 \mathrm{~h} 00$ to $15 \mathrm{~h} 00$, when the recording of meteorological variables was intensified, was characterized as the most critical time for the thermal discomfort of the birds, under both lighting systems.

Based on the literature, the animals are in thermal comfort when the BGTHI analyzed is between 74 and 77 . At values below 74, broilers are exposed to low temperatures while at values above 77 , their performance is hampered due to high temperatures.

According to Menegali et al. (2013) and based on data compared to those in the literature, values above 84 represent an emergency, requiring interventions such as ventilation, nebulization and surrounding landscaping to assist in the thermal comfort of the animals. Values close to 84 were observed at times between 13 and $15 \mathrm{~h}$ (Figure 2).
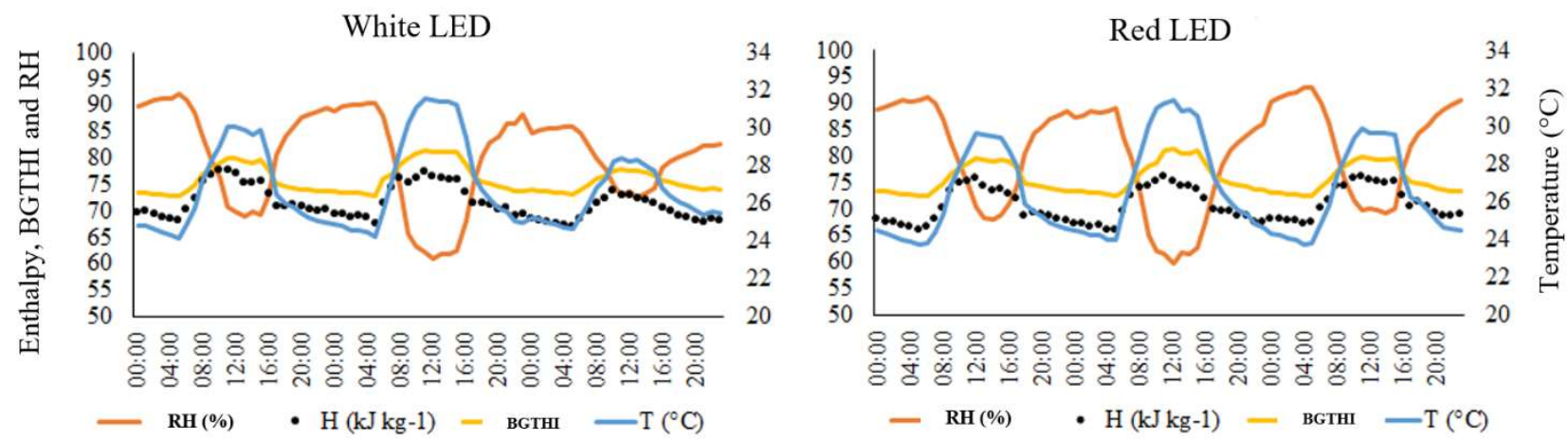

FIGURE 2. Thermal characterization of the environment for birds subjected to red LED and white LED.

According to Carvalho et al. (2014), in the winter period, BGTHI values were below 74 in the first weeks. At the other times and in the third week, BGTHI values were above the recommended, especially in the period between 12 and $15 \mathrm{~h}$, reaching values of up to 83 in the third week, a condition characterized as dangerous. In the second phase of the experiment, which occurred during the summer, BGTHI values were higher than 74, from 08:00 h, reaching the emergency condition from $11 \mathrm{~h}$.

According to Tinôco (1988), BGTHI values greater than 75 cause discomfort in broilers older than fifteen days, and this situation is aggravated as the birds develop. The variation of BGTHI occurs due to the combination of the effects of solar radiation and wind speed.

BGTHI values higher than 79 were found for birds subjected to red LED, reaching 80 in the $5^{\text {th }}$ week, from $09 \mathrm{~h} 00$ to $15 \mathrm{~h} 00$. For birds subjected to white LED, the values were higher than 77 , reaching 81 , also in the $5^{\text {th }}$ week of the production cycle. This demonstrates that the $5^{\text {th }}$ week had the highest values of BGTHI, but the birds suffered from discomfort from $09 \mathrm{~h} 00$ to $15 \mathrm{~h} 00$ from the 3rd week of rearing. 
At night, the BGTHI was equal to 74 for birds subjected to red LED and to 76 for those subjected to white LED. The lighting system has a greater influence on the behavior of birds at night, because during the day the effect of illuminance promoted by solar radiation interferes with the artificial lighting. From $09 \mathrm{~h} 00$ to $15 \mathrm{~h} 00$, the pen equipped with red LED received direct radiation on the frontal and longitudinal axis, which explains the initial BGTHI of 79 at this time.

Broilers subjected to white LED lights, at night, had BGTHI higher than 75, which caused discomfort.

The variation of enthalpy $(\mathrm{H})$, in the hourly interval from $09 \mathrm{~h} 00$ to $15 \mathrm{~h} 00$, was characteristic of discomfort, with values higher than $72.6 \mathrm{~kJ} / \mathrm{kg}$ of dry air, thus indicating loss in production due to the thermal stress experienced by the birds; at the other times, along the entire period studied, values classified as alert state were detected (Queiroz et al., 2012).
Thus, the thermal comfort indices BGTHI and $\mathrm{H}$ indicate that the micrometeorological conditions inside the facilities remained longer outside the zone considered comfort for broilers, especially in the afternoon, leading to stressful situations.

Figures 3 and 4 show the vectors and interrelationships for the frequencies of occurrences of the behaviors observed in the morning, afternoon and night.

Figure 3 shows that the first group corresponds to the occurrences of drinking and eating behaviors. These behaviors showed a high positive correlation with each other and a strong negative correlation with the inactivity behavior, according to the direction and orientation of vectors generated by PCA. The second group includes the thermal characteristics of the environment: temperature (T), Enthalpy (H), and BGTHI, and these variables have high positive correlation with each other and strong negative correlation with Humidity (RH).

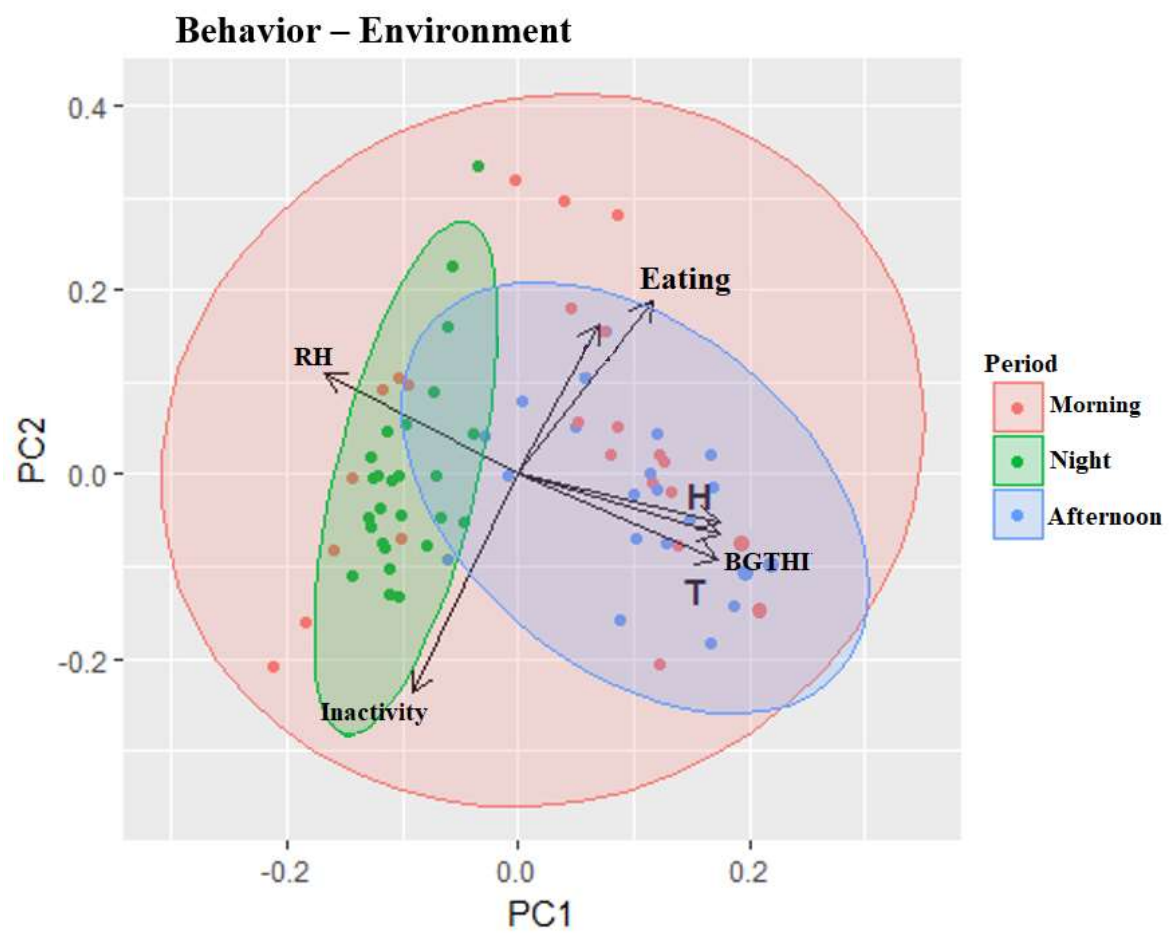

FIGURE 3. Principal component analysis to evaluate the frequency of occurrence of ingestive behavior as a function of environmental variables.

Figure 4 shows the influence of the lighting system on the behavior during the three periods of the day. Considering the behaviors of birds subjected to white LED lights (T3 and T4), there is an association between the behaviors "male eating" (T3E), "female eating" (T4E), and "female drinking" (T4D), that is, these behaviors belong to the same group, as they are occurring at the same frequency, which means that some broiler is always eating or drinking and it encourages other birds to do the same. 

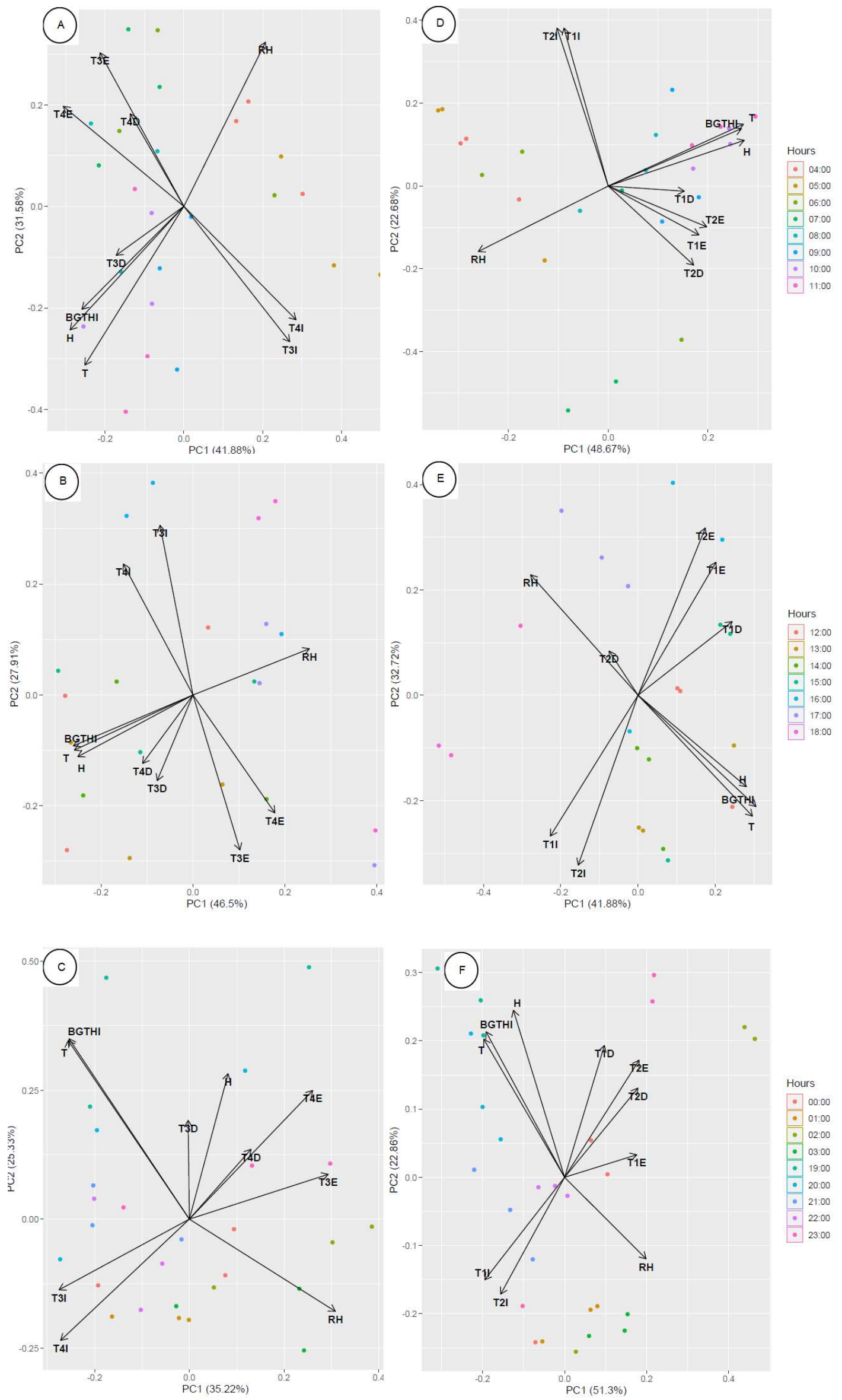

FIGURE 4. Principal component analysis comparing the frequency of occurrence of ingestive behavior as a function of environmental variables, for treatments with red LED and white LED. 
Another association observed in Figure 4 was of the "male drinking" behavior (T3D) with the thermal characteristics of the environment: Temperature (T), Enthalpy (H), and BGTHI, in the three periods, showing a positive correlation, because the act of drinking water is influenced by the variation of the thermal characteristics of the environment, which demonstrates that male broilers have greater sensitivity to the discomfort conditions imposed by the environment and the increase in water consumption would be a way to attenuate thermal discomfort.

In the night period, the "male eating" behavior (T3E) is negatively correlated with temperature and BGTHI, that is, if the temperature increases the birds eat less and, if it decreases, the birds eat more. Therefore, it is observed that the behavior of consuming food is related to the comfort and welfare provided by the environment.

Birds subjected to red LED (T1 and T2) showed a "female drinking" behavior (T2D) with strong negative correlation with temperature, BGTHI and $\mathrm{H}$ in the afternoon, which is justified by the fact that the broiler house has its longitudinal axis in the NE/SW direction, so solar radiation hits the area where the drinker was located, showing high negative correlation, which demonstrates that the birds suffered from thermal discomfort during this period of the day.

In the morning, birds subjected to red and white LED lights did not show behavioral changes, because the incidence of solar radiation is higher than the interference caused by the LED lights.

Figure 4 also shows that in the morning and afternoon periods, the "male drinking" behavior (T1D) was in the same group as the thermal variables of the environment, and the act of drinking more water occurs because males are heavier, with faster metabolism, more active than the female, and thus consuming more water.

Figure 5 shows the weekly weight gain of the birds subjected to the lighting systems. It can be observed that white LED lighting promoted greater weight gain than red LED lighting, which may be a consequence of the wavelength range provided by the white LED, which stimulated the broilers to consume more feed.

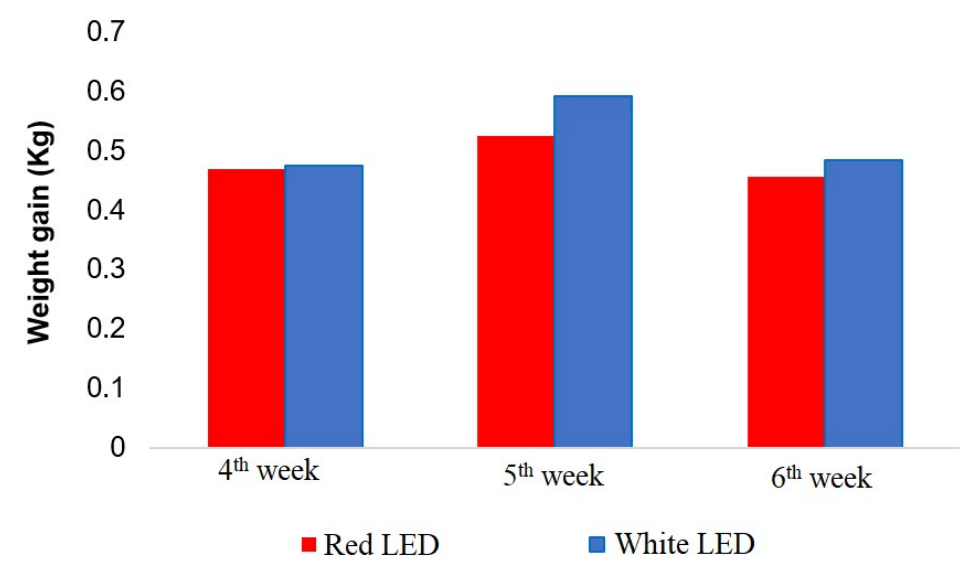

FIGURE 5. Productive performance of broilers as a function of lighting systems.

Figure 6 shows the variation in the broilers' body weight as a function of the ambient temperature for the last three weeks of rearing. It is observed that weight gain was quadratically influenced by temperature, and the highest body weights were observed at the temperature of $27.14^{\circ} \mathrm{C}$ in the $5^{\text {th }}$ week. Therefore, there is a $3.14^{\circ} \mathrm{C}$ increase in the ambient temperature, compared to the temperature recommended by the literature as indicative of thermal comfort (18-24 ${ }^{\circ} \mathrm{C}$ for $5^{\text {th }}$ week), and broilers kept at this temperature have higher feed efficiency, which was also found in the studies conducted by Cassuce et al. (2013) and Cândido et al. (2016). 
White LED

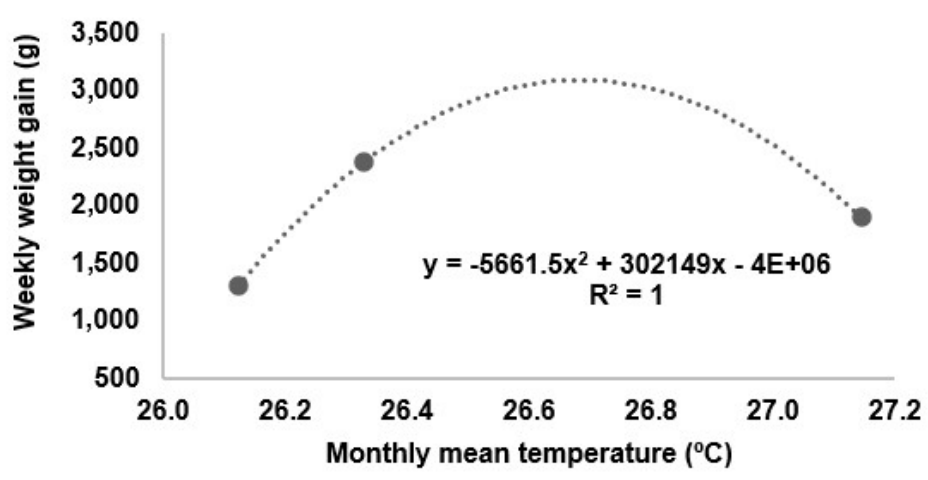

Red LED

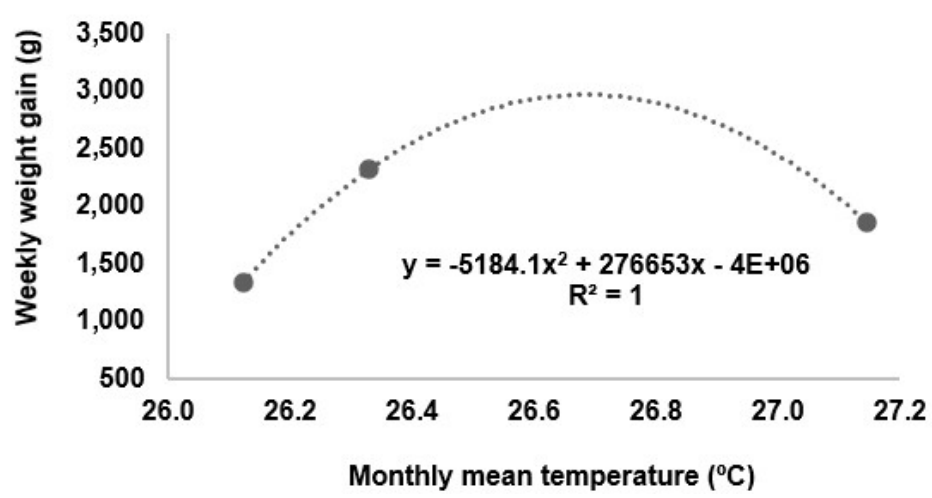

FIGURE 6. Effect of ambient temperature on weekly weight gain of broilers from $4^{\text {th }}$ to the $6^{\text {th }}$ week of rearing.

\section{CONCLUSIONS}

The ingestive behavior of broilers was influenced by the environment, especially in the morning and afternoon. At night, the influence of the white LED lighting system was more evident, due to the greater weight gain shown by the birds.

Birds subjected to the lighting systems did not show behavioral changes during the day, because the incidence of solar radiation is higher than the illuminance promoted by the lighting system.

Male broilers showed greater sensitivity to the discomfort conditions imposed by the environment, especially during the day.

The variation in body weight showed better response when the birds were exposed to temperature of $27^{\circ} \mathrm{C}$ in $5^{\text {th }}$ week of the rearing cycle.

\section{REFERENCES}

Abreu VMN, Abreu PG (2011) Os desafios da ambiência sobre os sistemas de aves no Brasil. Revista Brasileira de Zootecnia 40:8335-8338. Supl Especial.

Bergmann S, Schwarzer A, Wilutzky K, Louton H, JF, Schmidt P, Erhard M, Rauch E (2017) Behavior as welfare indicator for the rearing of broilers in an enriched husbandry environment-A field study. Journal of Veterinary Behavior: Clinical Applications and Research 19:90-101. DOI: https://doi.org/10.1016/j.jveb.2017.03.003-Journal of Veterinary Behavior v19p90-101/2017
Buffington DE, Collasso-Arocho A, Canton GH, Pitt D, Thatcher WW, Collier RJ (1981) Black globe-humidity index (BGHI) as comfort equation for dairy cows. Transactions of the ASAE 24(3):711-714. DOI: https://doi.org/10.13031/2013.34325-Transactions of the ASAE. American Society of Agricultural Engineers (TASABE) v24n3p711-714/1981

Cândido MGL, Tinôco IDFF, Pinto FDADC, Santos NT, Roberti RP (2016) Determinação da zona de conforto térmico para frangos de corte em estágio inicial.

Engenharia Agrícola 36(5):760-767. DOI:

https://dx.doi.org/10.1590/1809-4430-

Eng.Agric.v36n5p760-767/2016

Carvalho CCS, dos Santos TC, Silva, GC, Santos LV, Moreira SJM, Botelho LFR (2014) Conforto térmico animal e humano em galpões de frangos de corte no semiárido mineiro. Engenharia Agrícola e Ambiental 18(7):769-773. DOI: http://dx.doi.org/10.1590/S141543662014000700015-Engenharia-Agrícola-e-Ambiental v18n7p769-773/2014

Cassuce DC, Tinôco IDFF, Baêta FC, Zolnier S, Cecon PR, Vieira MDFA (2013) Atualização das temperaturas de conforto térmico para frangos de corte de até 21 dias de idade. Engenharia Agrícola 33(1):28-36. DOI: http://dx.doi.org/10.1590/S0100-69162013000100004Engenharia-Agrícola v33n1p28-36/2013 
Costa LS, Pereira DF, Bueno LGF, Pandorfi, H (2015)

Some aspects of chicken behavior and welfare. Ciências Avícola 14(3):159-164. DOI:

http://dx.doi.org/10.1590/S1516-635X2012000300001Ciências Avícola v14n3p159-164/2015

Menegali I, Tinoco IFF, Carvalho CCC, Souza CF, Martins JH (2013) Comportamento de variáveis climáticas em sistemas de ventilação mínima para produção de pintos de corte. Engenharia Agrícola e Ambiental 17(1):106-113. DOI: http://dx.doi.org/10.1590/S1415-

43662013000100015-Eng.agri.amb.v17n1p106-113/2013

Olanrewaju HA, Miller WW, Collier SD, Purswell JL, Branton SL (2016) Efeitos de fontes luminosas e intensidade em frangos de corte cultivados com pesos pesados. Parte 1: Desempenho de crescimento, características de carcaça e índices de bem-estar 1. Poultry Science 95(4):727-735. DOI: https://doi.org/10.3382/ps/pev360

Pereira AR, Angelocci LR, Sentelhas PC (2002) Agrometeorologia: fundamentos e aplicações práticas. Revista Agropecuária 10(2):251-257.

Queiroz MLV, Barbosa Filho JAD, Vieira FMC (2012) Avaliação do conforto térmico de frangos de corte de forma direta e prática. Revista "Produção Animal Avicultura. Available:

http://www.neambe.ufc.br/arquivos_publicao/2012101908 2929.pdf. Accessed: Jul 25, 2017.
Rodrigues VC, Silva IJO, Vieira FMC, Nascimento STA (2011) Correct entalphy relationship as thermal comfort index for livestock. International Journal Biometeorology 55(3):455-459. DOI https://doi.org/10.1007/s00484-0100344-y-International-Journal-Biometeorology-v55n3p455459/2011

Santana MRD, Garcia RG, Naas IDA, Paz ICDLA, Caldara FR, Barreto B (2014) Diodo emissor de luz (LED) na iluminação artificial de frangos de corte. Engenharia Agrícola 34(3):422-427. DOI: https://dx.doi.org/10.1590/S0100-69162014000300005

Schiassi L, Yanagi Junior T, Ferraz PFP, Campos AT, Silva GRE, Abreu LHP (2015) Comportamento de frangos de corte submetidos a diferentes ambientes térmicos. Revista Engenharia Agrícola 35(3)390-396. DOI: http://dx.doi.org/10.1590/1809-4430Eng.Agric.v35n3p390-396/2015

Silva TPN, Pandorfi H, Guiselini C (2015) Energy balance in the poultry-shed system and its influence on broiler performance. Engenharia Agrícola 35(4):613-624. DOI: http://dx.doi.org/10.1590/1809-4430Eng.Agric.v35n4p613-624/2015

Tinôco IFF (1988) Ambiência e instalações para a avicultura industrial. In: Encontro Nacional de Técnicos, Pesquisadores e Educadores de Construções Rurais, Poços de Caldas, Sociedade Brasileira de Engenharia Agrícola, p1-86. 